\title{
ANALISIS KONDISI HABITAT DAN PERAKARAN TUMBUHAN BAWAH PADA DAERAH TERBUKA DAN DI BAWAH TEGAKAN CEMARA UDANG DI PESISIR LEMBUPURWO, KEBUMEN
}

\author{
Winastuti DWi AtManto, Hesti Wulan NdARI, SRi DANARTo
}

Fakultas Kehutanan, Universitas Gadjah Mada, Jalan Agro No. 1, Bulaksumur, Yogyakarta 55281

\section{A B S T R A C T}

Coastal sandy soil without trees is characterized by a high temperature, salinity, strong wind, as well as lacking nutrient content. The environmental conditions limit affects the variety of undergrowths. This research aimed to figure out the composition, distribution pattern, habitat condition and rooting of brushes species found on coastal sandy areas at the Lemburpurwo. The study was conducted using line transect method applying systematic sampling with a random start. The observations of undergrowths were carried out on the three types of threads, i.e., near the sea, under the beach-she-oak stands locally know as Cemara Udang, and behind the beach-she-oak stands with no trees. Transects were made perpendicular approximately $53 \mathrm{~m}$ from the shoreline, and the distance between transects was $95 \mathrm{~m}$. A series of $2 \times 2 \mathrm{~m}^{2}$ plots were laid diagonally (zigzag) across the transect line for undergrowths sample collection. 81 plots were taken, represented the Lemburpurwo area covering $72,960 \mathrm{~m}^{2}$. Scrubs plant species were identified, the length and number of roots were measured, environmental conditions and soil condition including $\mathrm{pH}$, conductivity, total $\mathrm{N}$, available $\mathrm{P}$, and available $\mathrm{K}$ were also measured. Lembupurwo coastal sandy area was inhabited by 20 species of 13 families of undergrowths. Three species were found randomly distributed, and 17 species were found in a clustered distribution pattern. Spinifex littoralis has the longest root as well as the largest number of roots, especially in open areas. The measured values of soil pH and conductivity below the stands were 6.41 and 32.23 $\mu \mathrm{s} / \mathrm{cm}$ lower compared to near the sea site. Total $\mathrm{N}$ and available $\mathrm{P}$ of the soil under beach-she-oak stands were $0.03 \%$ and $5.05 \mathrm{ppm}$ which higher than the other two locations.

KEY WORDS: coastal sandy areas, undergrowth, habitat, rooting

Penulis korespondensi: WinASTUTI Dwi ATMANTo | email: winastuti_da@ugm.ac.id

Dikirim: 06-06-2017 | Diterima: 31-08-2017

\section{PEN D A H U L U A N}

Kawasan pesisir merupakan kawasan yang memiliki beberapa keterbatasan di antaranya adalah memiliki suhu, penguapan, kecepatan angin, dan kandungan garam yang tinggi, serta miskin bahan organik. Suatu kondisi yang menyebabkan hanya tumbuhan tertentu yang mampu tumbuh di lingkungan tersebut (Soegianto, 1983). Salah satu jenis pohon yang mampu tumbuh dengan baik di wilayah pesisir adalah Casuarina equisetifolia var. incana atau dikenal dengan Cemara Udang. Tumbuhan tersebut mampu membuat kondisi pertanaman yang ideal dengan menyuburkan tanah dan menciptakan iklim mikro untuk tanaman lain (Whistler \& Craig, 2006). Atmanto (2013) menjelaskan bahwa kadar nitrogen lahan pasir pantai yang tidak ditumbuhi Cemara Udang berubah dari $0,01 \%$ menjadi $0,04 \%$ setelah ditanami Cemara Udang, pertambahan setara dengan 308-604 kgN/ha. Adanya tegakan Cemara Udang di lahan pasir akan menghasilkan bahan organik sebagai bahan utama tersedianya unsur nitrogen. Sebagian besar nitrogen yang dihasilkan tersebut berasal dari aktivitas mikroorganisme terutama frankia yang mampu menambat nitrogen dari udara.

Cemara Udang mampu tumbuh pada kondisi lingkungan yang ekstrim, tahan kekeringan, dan hembusan angin yang kuat, serta serangan hama penyakit (Rao \& Dommergues, 1998). Cemara Udang juga mampu hidup pada daerah miskin hara dan merupakan salah satu jenis pioner di kawasan pesisir yang rawan abrasi (Dommergues, 1990).

Keberhasilan penanaman Cemara Udang sebagai penahan angin juga bermanfaat bagi perkembangan tanaman pertanian. Tanaman ini dapat dimanfaatkan sebagai kayu bakar, kayu kontruksi, penahan gerakan pasir, penghijauan, peneduh, dan tanaman hias sehingga keberadaannya di areal pesisir pantai sangat bermanfaat baik bagi masyarakat sekitar maupun bagi ekosistem areal pesisir tersebut (Winarni, 2002).

Struktur tajuk pada lapisan di bagian bawah hutan, biasanya ditumbuhi oleh sekelompok tumbuhan yang sering disebut dengan vegetasi bawah. Kehadiran tumbuhan bawah diharapkan mampu memberikan stabilitas dalam ekosistem, melindungi tanah dari kondisi terbuka, dan memelihara kesuburan tanah (Dombois dan Ellenberg, 1974). Jenis tumbuhan yang dapat tumbuh pada kawasan pesisir dibatasi oleh faktor lingkungan seperti kurangnya unsur hara, kadar garam yang tinggi, angin yang kencang, dan suhu yang terlalu tinggi. Hal tersebut menyebabkan dijumpainya berbagai pola distribusi spasial seperti acak, teratur, maupun mengelompok (Barbour et al., 1980). Pola distribusi spasial tumbuhan merupakan karakteristik ekologi yang penting bagi suatu komunitas (Ludwig dan Reynolds, 1988). Pola tersebut berkaitan erat dengan hubungan timbal balik antara faktor lingkungan, keadaan ko-aktif sebagai hasil interaksi spesifik seperti kompetisi, dan reproduksi masing-masing jenis (Whittaker, 1975).

Penelitian ini mencoba menjelaskan komposisi, pola sebaran, kondisi habitat, dan perakaran jenis tumbuhan bawah di kawasan pesisir Lembupurwo, Kebumen. Kawasan pesisir Lembupurwo ini merupakan contoh lokasi yang berhasil direklamasi dengan jenis Cemara Udang pada tahun 2008, dan saat ini di bawah tegakan banyak dijumpai jenis 
tumbuhan bawah. Penelitian dilakukan dengan mengidentifikasi jenis tumbuhan bawah beserta nilai frekuensi ditemukannya jenis sehingga dapat diketahui komposisi dan pola sebaran, serta kondisi habitat dan perakaran dari masing-masing jenis tumbuhan bawah yang terdapat di kawasan pesisir Lembupurwo. Komposisi dan pola sebaran jenis akan memberikan informasi mengenai keragaman jenis dan pola persebaran tumbuhan bawah dalam mendukung kestabilan suatu ekosistem khususnya di areal pesisir.

Tujuan penelitian ini adalah umtuk mengetahui komposisi dan pola sebaran jenis tumbuhan bawah, serta mengetahui kondisi habitat dan perakaran dari jenis tumbuhan bawah yang ditemukan di kawasan pesisir Lembupurwo.

\section{MET ODE}

Penelitian ini dilakukan pada tahun 2016, pada tegakan Cemara Udang yang berumur 8 tahun, di kawasan pasir pantai Lembupurwo, Kebumen, Jawa Tengah. Obyek yang digunakan dalam penelitian adalah tumbuhan bawah berupa herba dan perdu. Peralatan yang digunakan yaitu meteran, penggaris, alat ukur kondisi lingkungan, dan alat untuk pembuatan profil tanah.

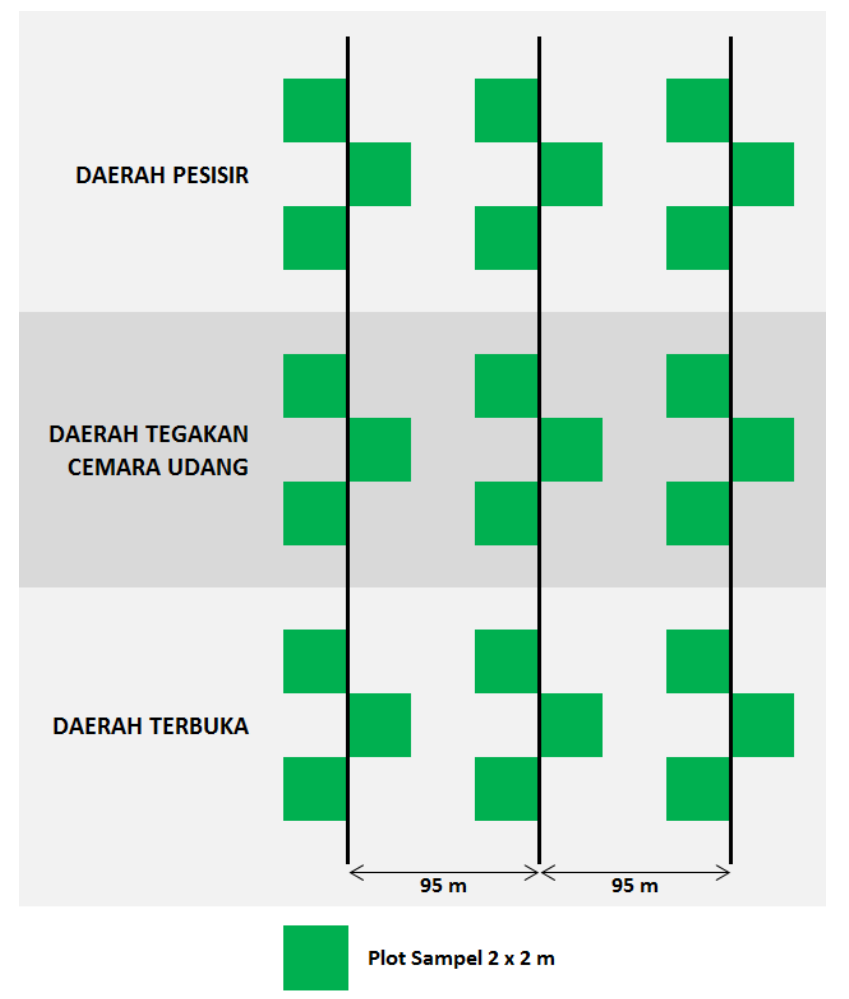

Gambar 1. Diagram skematis jalur dan plot penelitian

Penelitian dilakukan dengan metode line transect yang ditetapkan secara systematic sampling with random start. Terdapat 3 lokasi pengambilan sampel yaitu dekat laut, di bawah tegakan Cemara Udang, dan di belakang tegakan (daerah terbuka dan tidak terdapat tegakan Cemara Udang). Jalur tegak lurus yang berjarak sekitar $53 \mathrm{~m}$ dari garis pantai dibuat dengan jarak antar jalur $95 \mathrm{~m}$. Tiap jalur dibagi menjadi segmen-segmen berupa petak ukur berukuran $2 \times 2 \mathrm{~m}^{2}$ yang diletakkan secara diagonal antar petak untuk pengamatan tumbuhan bawah (Gambar 1). Total petak ukur yang diambil sebanyak 81 plot, dari kawasan seluas $72.960 \mathrm{~m}^{2}$.
Pengambilan data tumbuhan bawah yang dilakukan di dalam petak ukur $2 \times 2 \mathrm{~m}^{2}$ meliputi; identifikasi jenis tumbuhan bawah, pola sebaran tumbuhan bawah, dan kondisi biofisik habitat. Data dianalisis dengan menghitung; indeks nilai penting yang mengacu pada Dombois \& Ellenberg (1974). Pola distribusi spasial mengacu pada kriteria nilai dari indeks Morista. Kondisi habitat diketahui dengan menghitung besarnya intensitas cahaya, suhu udara, kelembaban, kecepatan angin, dan suhu tanah dari masingmasing lokasi penelitian, serta sifat kimia tanah dengan menganalisis $\mathrm{N}$-total, $\mathrm{P}$-tersedia, K-tersedia, $\mathrm{pH}$ tanah, dan daya hantar listrik. Kondisi tanah dari masing-masing parameter dihitung berdasarkan rata-rata yang dihasilkan dari masing-masing profil tanah yang berada pada tiap lokasi penelitian (tiap lokasi terdiri dari 3 profil tanah).

\section{HASIL DAN PEMBAHASAN}

Keasaman tanah pada ketiga lokasi penelitian mendekati netral. Nilai $\mathrm{pH}$ tanah tertinggi terdapat pada daerah dekat laut 6,74, di belakang tegakan 6,59, dan di bawah tegakan 6,41. pH pada daerah dekat laut paling tinggi di sebabkan oleh adanya kandungan garam terlarut di dalam tanah yang dipengaruhi oleh penguapan yang tinggi. Menurut Hardjowigeno (1987), pentingnya $\mathrm{pH}$ tanah yaitu sebagai penentu mudah tidaknya unsur-unsur hara diserap tanaman. Pada umumnya unsur hara mudah diserap akar tanaman pada $\mathrm{pH}$ tanah sekitar netral, karena pada $\mathrm{pH}$ tersebut kebanyakan unsur hara mudah larut dalam air.

Tabel 1. Kondisi tanah di kawasan pesisir Lembupurwo

\begin{tabular}{lccccc}
\hline Lokasi & $\mathbf{p H}$ & $\begin{array}{c}\mathbf{N} \\
\mathbf{( \% )}\end{array}$ & $\begin{array}{c}\mathbf{P} \\
(\mathbf{p p m})\end{array}$ & $\begin{array}{c}\mathbf{K} \\
(\mathbf{m e} / \mathbf{1 0 0 g})\end{array}$ & $\begin{array}{c}\text { DHL } \\
(\boldsymbol{\mu} \mathbf{\text { s }} \mathbf{c m})\end{array}$ \\
\hline Dekat laut & 6,74 & 0,01 & 4,27 & 0,14 & 48,70 \\
Bawah tegakan & 6,41 & 0,03 & 5,05 & 0,14 & 32,23 \\
Belakang tegakan & 6,59 & 0,02 & 4,53 & 0,12 & 33,37 \\
\hline
\end{tabular}

Hasil analisis menunjukkan kandungan unsur hara $\mathrm{N}$-total dalam tanah pada kawasan pesisir Lembupurwo tergolong rendah. Sementara itu, untuk unsur hara P-tersedia dalam tanah juga rendah. Hasil analisis laboratorium menunjukkan bahwa unsur hara K-tersedia memiliki jumlah kandungan di atas 0,1 me/100g dan tergolong rendah. Berdasarkan hasil yang diperoleh, dapat diketahui bahwa tidak terdapat perbedaan yang signifikan antara kandungan N-total, P-tersedia dan K-tersedia yang terdapat pada daerah dekat laut, bawah tegakan, dan di belakang tegakan Cemara Udang. Hasil analisis terhadap daya hantar listrik menunjukkan daya hantar listrik paling tinggi berada pada daerah dekat laut 48,70 $\mu \mathrm{s} / \mathrm{cm}$, daerah di belakang tegakan $33,37 \mu \mathrm{s} / \mathrm{cm}$, dan di bawah tegakan $32,23 \mu \mathrm{s} / \mathrm{cm}$.

Berdasarkan Tabel 2. dapat diketahui bahwa intensitas cahaya dan suhu lingkungan tertinggi terdapat pada daerah di belakang tegakan Cemara Udang. Sementara untuk kelembaban paling tinggi terdapat pada daerah di bawah tegakan, kecepatan angin tertinggi terdapat pada daerah dekat laut, serta suhu tanah tertinggi terdapat pada daerah dekat laut dan di belakang tegakan. 
Tabel 2. Kondisi lingkungan di kawasan pesisir Lembupurwo

\begin{tabular}{|c|c|c|c|c|c|c|c|c|c|c|c|c|c|}
\hline \multirow[t]{2}{*}{ Lokasi } & \multicolumn{3}{|c|}{$\begin{array}{c}\text { Intensitas Cahaya } \\
\text { (lux) }\end{array}$} & \multicolumn{3}{|c|}{$\begin{array}{c}\text { Suhu Lingkungan } \\
\left({ }^{\circ} \mathrm{C}\right)\end{array}$} & \multicolumn{3}{|c|}{$\begin{array}{c}\text { Kelembaban } \\
\text { (\%) }\end{array}$} & \multicolumn{3}{|c|}{$\begin{array}{l}\text { Kecepatan Angin } \\
(\mathrm{km} / \mathrm{s})\end{array}$} & \multirow[t]{2}{*}{$\begin{array}{c}\text { Suhu Tanah } \\
\left({ }^{\circ} \mathrm{C}\right)\end{array}$} \\
\hline & Pagi & Siang & Sore & Pagi & Siang & Sore & Pagi & Siang & Sore & Pagi & Siang & Sore & \\
\hline Dekat laut & $693 \times 100$ & $917 \times 100$ & $551 \times 100$ & 33,9 & 40,8 & 32,9 & 47,8 & 43,2 & 59,9 & 1,6 & 2,6 & 1,8 & 31,00 \\
\hline Bawah tegakan & $240 \times 100$ & $350 \times 100$ & $217 \times 100$ & 31,5 & 32,5 & 29,5 & 74,4 & 73,0 & 75,8 & 0,8 & 1,8 & 1,3 & 27,07 \\
\hline Belakang tegakan & $662 \times 100$ & $975 \times 100$ & $560 \times 100$ & 45,0 & 55,2 & 31,4 & 43,5 & 35,6 & 68,2 & 1,3 & 2,2 & 1,6 & 31,00 \\
\hline
\end{tabular}

Tabel 3. Jenis tumbuhan bawah di kawasan pesisir Lembupurwo

\begin{tabular}{|c|c|c|c|c|c|c|c|}
\hline No Nama Spesies & Nama Famili & Nama Lokal & Habitus & Indeks Morisita & X hitung & X tabel & Pola Sebaran \\
\hline 1. Emilia sonchifolia (L) DC. ex Wight & Asteraceae & Tempuh wiyang & Herba & 1,721 & 163,72 & 60,391 & Mengelompok \\
\hline 2. Porophyllum ruderale (Jacq.) Cass. & Asteraceae & Ketumbar bolivia & Perdu & 1,247 & 409,99 & 60,391 & Mengelompok \\
\hline 3. Wedelia biflora (L.) DC. & Asteraceae & Seruni & Herba & 1,878 & 1655,68 & 60,391 & Mengelompok \\
\hline 4. Elephantopus spicatus B. Juss. ex Aubl. & Asteraceae & Tapak liman & Herba & 1,929 & 81,00 & 60,391 & Mengelompok \\
\hline 5. Ipomoea pes-caprae (L.) R.Br. & Convolvulaceae & Tapak kuda & Herba & 1,311 & 821,80 & 60,391 & Mengelompok \\
\hline 6. Bulbustylis barbata (Rottb.) C.B. Clarke & Cyperaceae & Rumput teki & Herba & 1,759 & 81,00 & 60,391 & Mengelompok \\
\hline 7. Desmodium triflorum (L.) DC. & Fabaceae & Daun mules & Herba & 1,451 & 81,00 & 60,391 & Mengelompok \\
\hline 8. Coleus parfiflorus Benth. & Lamiaceae & Langon & Herba & 1,737 & 163,74 & 60,391 & Mengelompok \\
\hline 9. Salvia divinorum & Lamiaceae & Sage & Herba & 1,965 & 81,00 & 60,391 & Mengelompok \\
\hline 10. Abutilon pictum (Gillies) Walp. & Malvaceae & Waron & Perdu & 1,497 & 245,99 & 60,391 & Mengelompok \\
\hline 11. Passiflora foetida $\mathrm{L}$. & Passifloraceae & Rambusa & Perdu & 1,242 & 1643,60 & 60,391 & Mengelompok \\
\hline 12. Panicum repens $\mathrm{L}$. & Poaceae & Rumput lempuyangan & Herba & 1,274 & 81,00 & 60,391 & Mengelompok \\
\hline 13. Cynodon dactylon (L.) Pers. & Poaceae & Rumput bermuda & Herba & 1,214 & 163,21 & 60,391 & Mengelompok \\
\hline 14. Spinifex littoralis (Burm.f.) Merr. & Poaceae & Rumput grinting & Herba & 1,258 & 163,26 & 60,391 & Mengelompok \\
\hline 15. Portulaca oleracea L. & Portulacaceae & Krokot & Perdu & 2,361 & 247,72 & 60,391 & Mengelompok \\
\hline 16. Borreria leavis (Lamk.) Griseb. & Rubiaceae & Ketumpang & Perdu & 1,252 & 1475,00 & 60,391 & Mengelompok \\
\hline 17. Borreria sp. & Rubiaceae & Berokan & Perdu & 2,094 & 1244,32 & 60,391 & Mengelompok \\
\hline 18. Solanum sp. & Solanaceae & Terongan & Herba & 1,000 & 163,00 & 60,391 & Acak \\
\hline 19. Stachytarpheta indica (L.) Vahl & Verbenaceae & Pecut kuda & Herba & 1,000 & 163,00 & 60,391 & Acak \\
\hline 20. Cayratia trifolia (L.) Domin & Vitaceae & Galing & Herba & 1,000 & 3700,07 & 60,391 & Acak \\
\hline
\end{tabular}

Perbedaan suhu tanah ini dipengaruhi oleh kondisi pada daerah di bawah tegakan, pada daerah ini terdapat pohon Cemara Udang yang tumbuh disepanjang lokasi, sehingga dengan adanya pohon tersebut, penutupan lahan oleh tanaman lebih tinggi dan menghasilkan suhu tanah yang lebih rendah. Semakin rapat suatu tegakan, maka celah antar tajuk semakin sempit sehingga intensitas cahaya yang mampu mencapai lantai hutan juga semakin rendah, dan suhu tanah yang dihasikan juga akan rendah.

Pada lokasi penelitian ditemukan 20 jenis tumbuhan bawah dari 13 familia. Perbandingan jenis tumbuhan bawah pada masing-masing plot penelitian cukup bervariasi. Pada daerah dekat laut, jenis tumbuhan bawah yang ditemukan 6 jenis, di bawah tegakan 12 jenis, sementara pada daerah di belakang tegakan 14 jenis. Keterbatasan kondisi lingkungan pesisir menyebabkan terbatasnya tumbuhan bawah yang mampu tumbuh, dan hanya jenis-jenis tertentu yang mampu tumbuh baik pada lokasi penelitian. Hal ini tidak lepas dari pengaruh faktor lingkungan dan seleksi alam, dimana akan memengaruhi jenis tumbuhan bawah yang mampu tumbuh dengan baik pada kondisi tertentu. Kesesuaian jenis terhadap lingkungannya sangat memengaruhi jenis tumbuhan bawah yang mampu tumbuh dengan baik pada kondisi pesisir, khususnya di kawasan pesisir Lembupurwo.

Jenis tumbuhan bawah yang ditemukan di kawasan pesisir Lembupurwo hanya 20 jenis. Kawasan pesisir dengan karakteristik suhu, penguapan, kecepatan angin, dan kandungan garam yang tinggi, serta miskin bahan organik menyebabkan hanya jenis-jenis tertentu yang mampu tumbuh pada kawasan tersebut. Kesesuaian jenis terhadap lingkungannya sangat memengaruhi jenis tumbuhan bawah yang mampu tumbuh dengan baik pada kondisi pesisir, khususnya di kawasan pesisir Lembupurwo.

Pada penelitian ini diketahui 3 jenis tumbuhan bawah memiliki pola sebaran acak dan 17 jenis memiliki pola sebaran mengelompok. Pola distribusi acak menunjukkan bahwa tumbuhan bawah responsif terhadap kondisi tempat tumbuh. Selain itu, pola persebaran acak juga disebabkan oleh adanya pengaruh angin yang berhembus. Angin mempunyai peran yang sangat besar untuk membantu individu dalam membentuk pola distribusi secara acak karena biji dari tumbuhan akan terbawa oleh angin sehingga biji dari individu akan tersebar secara luas. Hal ini akan menciptakan individu membentuk pola distribusi secara acak lebih tinggi.

Di lokasi penelitian tumbuhan bawah didominasi oleh pola persebaran secara mengelompok. Hal ini karena tumbuhan bawah yang mengelompok dipengaruhi oleh faktor lingkungan dan kondisi habitat tempat tumbuh, seperti pengaruh intensitas cahaya, suhu, kelembaban, maupun ketersediaan unsur hara dan air, sehingga jenis-jenis tertentu berkumpul pada area yang menguntungkan. Disamping itu, pola persebaran mengelompok juga dapat dipengaruhi oleh cara reproduksi jenis tumbuhan bawah. Menurut Alik et al. (2012), pola penyebaran mengelompok umumnya dijumpai di alam, karena adanya kebutuhan akan faktor lingkungan yang sama.

Berdasarkan Tabel 4 diketahui perbandingan indeks nilai penting tumbuhan bawah pada daerah dekat laut, di bawah tegakan, dan di belakang tegakan. Pada daerah dekat laut jenis Spinifex littoralis mempunyai indeks nilai penting paling tinggi dibandingkan dengan tumbuhan bawah lainnya. 
Tabel 4. Struktur jenis tumbuhan bawah (\%) di pesisir Lembupurwo

\begin{tabular}{|c|c|c|c|c|c|c|c|c|c|c|}
\hline \multirow[b]{2}{*}{ No } & \multirow[b]{2}{*}{ Nama Spesies } & \multicolumn{3}{|c|}{ Dekat laut } & \multicolumn{3}{|c|}{ Bawah tegakan } & \multicolumn{3}{|c|}{ Belakang tegakan } \\
\hline & & $\begin{array}{r}\text { Frekuensi } \\
\text { Relatif }\end{array}$ & $\begin{array}{r}\text { Kerapatan } \\
\text { Relatif }\end{array}$ & $\begin{array}{r}\text { Indeks } \\
\text { Nilai } \\
\text { Penting } \\
\end{array}$ & $\begin{array}{r}\text { Frekuensi } \\
\text { Relatif }\end{array}$ & $\begin{array}{r}\text { Kerapatan } \\
\text { Relatif }\end{array}$ & $\begin{array}{r}\text { Indeks } \\
\text { Nilai } \\
\text { Penting }\end{array}$ & $\begin{array}{r}\text { Frekuensi } \\
\text { Relatif }\end{array}$ & $\begin{array}{r}\text { Kerapatan } \\
\text { Relatif }\end{array}$ & $\begin{array}{r}\text { Indeks } \\
\text { Nilai } \\
\text { Penting }\end{array}$ \\
\hline 1. & Emilia sonchifolia (L) DC. ex Wight & 1,96 & 0,92 & 2,88 & 2,00 & 0,50 & 2,50 & & & \\
\hline 2. & Porophyllum ruderale (Jacq.) Cass. & & & & 18,00 & 14,36 & 32,36 & 1,82 & 2,16 & 3,98 \\
\hline 3. & Wedelia biflora (L.) DC. & & & & 2,00 & 0,99 & 2,99 & & & \\
\hline 4. & Elephantopus spicatus B. Juss. ex Aubl. & 1,96 & 1,83 & 3,80 & 2,00 & 1,49 & 3,49 & & 6,49 & 6,49 \\
\hline 5. & Ipomoea pes-caprae (L.) R.Br. & 25,49 & 16,51 & 42,00 & 4,00 & 0,99 & 4,99 & 5,45 & 1,30 & 6,75 \\
\hline 6. & Bulbustylis barbata (Rottb.) C.B. Clarke & & & & & & & 1,82 & 1,73 & 3,55 \\
\hline 7. & Desmodium triflorum (L.) DC. & & & & & & & 3,64 & 6,06 & 9,70 \\
\hline 8. & Coleus parfiflorus Benth. & & & & 4,00 & 5,94 & 9,94 & & & \\
\hline 9. & Salvia divinorum & & & & & & & 5,45 & 18,61 & 24,07 \\
\hline 10. & Abutilon pictum (Gillies) Walp. & & & & 2,00 & 0,50 & 2,50 & & & \\
\hline 11. & Passiflora foetida $\mathrm{L}$. & & & & & & & 1,82 & 2,16 & 3,98 \\
\hline 12. & Panicum repens $\mathrm{L}$. & & & & 8,00 & 8,91 & 16,91 & 1,82 & 1,30 & 3,12 \\
\hline 13. & Cynodon dactylon (L.) Pers. & & & & 34,00 & 40,59 & 74,59 & 5,45 & 2,60 & 8,05 \\
\hline 14. & Spinifex littoralis (Burm.f.) Merr. & 49,02 & 62,39 & 111,40 & & & & 36,36 & 22,94 & 59,31 \\
\hline 15. & Portulaca oleracea $\mathrm{L}$. & & & & & & & 3,64 & 2,16 & 5,80 \\
\hline 16. & Borreria leavis (Lamk.) Griseb. & 11,76 & 11,93 & 23,69 & & & & 25,45 & 26,84 & 52,29 \\
\hline 17. & Borreria sp. & & & & & & & 5,45 & 5,19 & 10,65 \\
\hline 18. & Solanum sp. & 9,80 & 6,42 & 16,23 & 18,00 & 24,26 & 42,26 & 1,82 & 0,43 & 2,25 \\
\hline 19. & Stachytarpheta indica (L.) Vahl & & & & 4,00 & 0,99 & 4,99 & & & \\
\hline 20. & Cayratia trifolia (L.) Domin & & & & 2,00 & 0,50 & 2,50 & & & \\
\hline & Total & 100,00 & 100,00 & 200,00 & 100,00 & 100,00 & 200,00 & 100,00 & 100,00 & 200,00 \\
\hline
\end{tabular}

Tabel 5. Keanekaragaman, kekayaan, dan kemerataan jenis tumbuhan bawah di pesisir Lembupurwo

\begin{tabular}{|c|c|c|c|c|c|}
\hline Lokasi & Jumlah Individu & Komposisi Jenis & Indeks Keanekaragaman & Indeks Kekayaan & Indeks Kemerataan \\
\hline Dekat laut & 109 & 6 & 1,138 & 1,066 & 0,635 \\
\hline Bawah tegakan & 202 & 12 & 1,650 & 2,072 & 0,664 \\
\hline Belakang tegakan & 231 & 14 & 2,055 & 2,389 & 0,779 \\
\hline
\end{tabular}

Perbandingan nilai penting masing-masing jenis pun cukup bervariasi, jenis Spinifex littoralis memiliki nilai penting terbesar 111,4\%, kemudian Ipomoea pescaprae 42\%, Borreria leavis 23,69\%, Solanum sp. 16,23\%, Elephantopus spicatus 3,8\%, dan Emilia sonchifolia 2,88\%, sementara jenis lainnya tidak ditemukan pada daerah tersebut.

Pada daerah di bawah tegakan, Cynodon dactylon mempunyai nilai penting paling tinggi dibandingkan jenis tumbuhan bawah lainnya yaitu 74,59\%, kemudian Solanum sp. 42,26\%, Porophyllum ruderale $32,36 \%$, Panicum repens 16,91\%, Coleus parfiflorus 9,94\%, Stachytarpheta indica 4,99\%, Ipomoea pescaprae 4,99\%, Elephantopus spicatus 3,49\%, Wedelia biflora 2,99\%, Emilia sonchifolia 2,50\%, Abutilon pictum 2,50\%, dan Cayratia triflolia 2,50\%.

Pada daerah di belakang tegakan, Spinifex littoralis mempunyai nilai penting paling tinggi dibandingkan jenis tumbuhan bawah lainnya yaitu 59,31\%, diikuti oleh Borreria leavis 52,29\%, Salvia divinorum 24,07\%, Borreria sp. 10,65\%, Desmodium triflorum 9,70\%, Cynodon dactylon 8,05\%, Ipomoea pes-caprae 6,75\%, Elephantopus spicatus 6,49\%, Portulaca oleracea 5,8\%, Passiflora foetida 3,98\%, Porophyllum ruderale $3,98 \%$, Bulbustylis barbata 3,55\%, Panicum repens $3,12 \%$, dan Solanum sp. 2,25\%.

Indeks nilai penting menggambarkan intervensi suatu jenis terhadap jenis lainnya. Indeks nilai penting jenis tumbuhan bawah memperlihatkan kepentingan atau peranan jenis tersebut dalam komunitas tumbuhan yang dipengaruhi oleh kondisi tempat tumbuh. Jenis yang mempunyai peranan besar akan mempunyai indeks nilai penting yang tinggi karena indeks nilai penting ditentukan oleh kerapatan relatif dan frekuensi relatif. Raymond (2010) menjelaskan bahwa jenis tumbuhan yang memiliki INP $\geq 10 \%$ merupakan jenis tumbuhan bawah yang mempunyai peranan penting dan merupakan penyusun utama dalam suatu komunitas.

Keanekaragaman jenis pada tiap lokasi penelitian tergolong sedang dengan nilai indeks berkisar antara 1-2. Hal ini sesuai dengan konsep keanekaragaman jenis, dimana nilai indeks berkisar 1-3 termasuk memiliki keanekaragaman sedang. Sementara dari nilai indeks kekayaan jenis diketahui bahwa tiap lokasi juga memiliki kekayaan jenis yang tergolong rendah. Berdasarkan kategori penetapan kekayaan jenis Margalef, jika nilai indeks kekayaan jenis kurang dari 3,5, maka kekayaan jenis termasuk rendah. Nilai indeks kemerataan jenis pada tiap lokasi menunjukan penyebaraan yang relatif merata, yaitu mendekati 1 . Hal ini sesuai dengan konsep kemerataan jenis, jika nilai indeks sama dengan 1, maka persebaran jenis adalah merata.

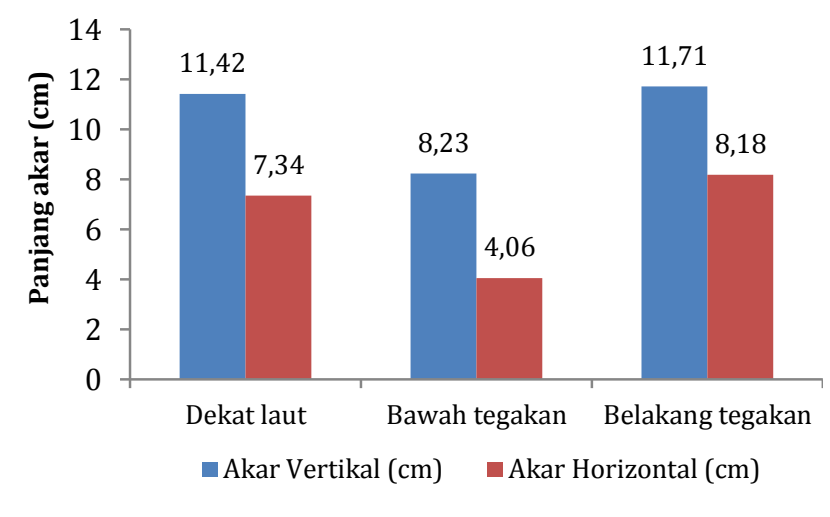

Lokasi Penelitian

Gambar 2. Grafik perbandingan panjang akar tumbuhan bawah di pesisir Lembupurwo 


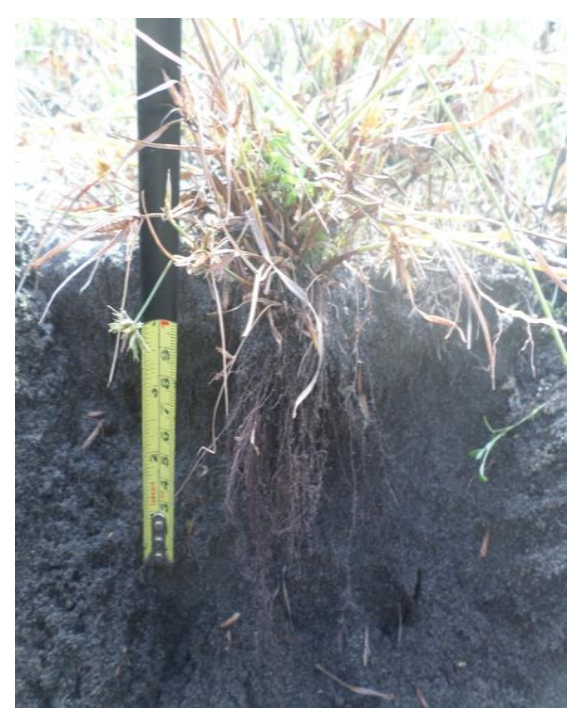

A. Bulbustylis barbata

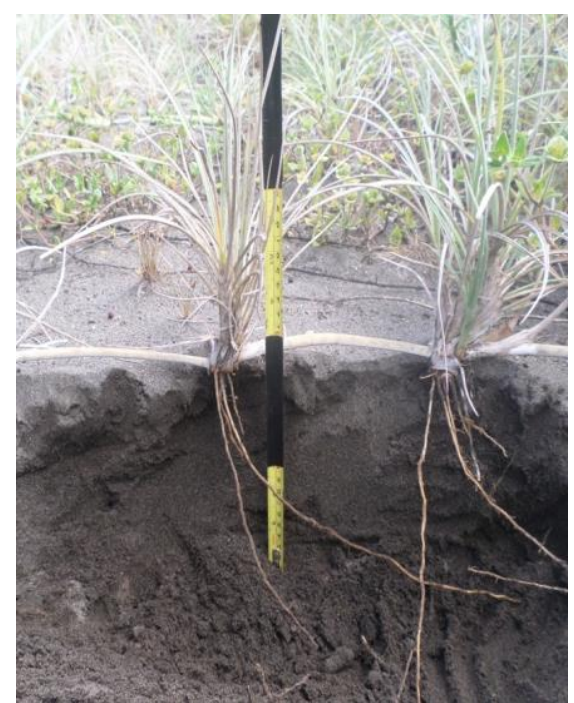

D. Spinifex littoralis

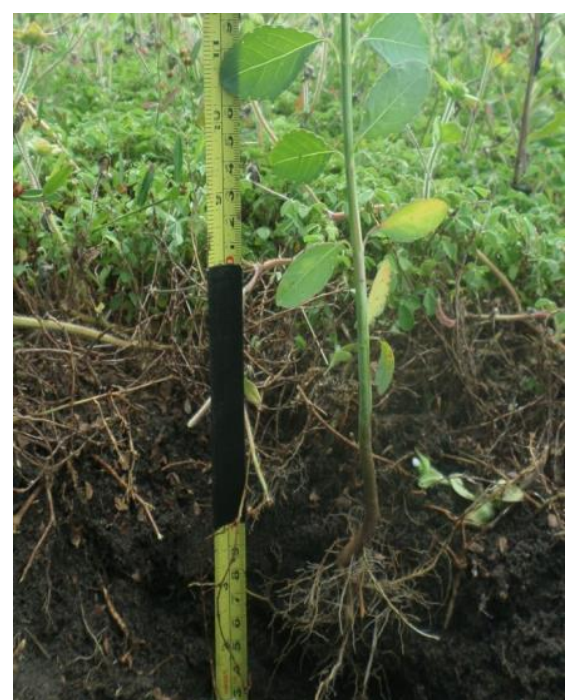

G. Porophyllum ruderale

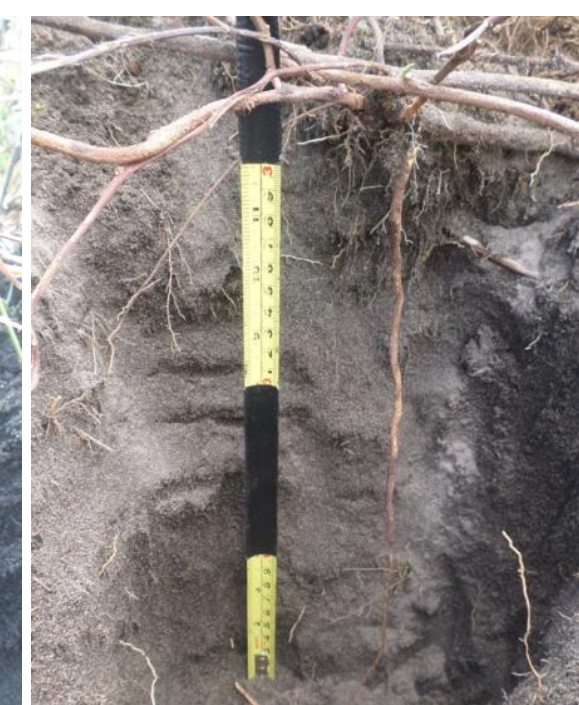

B. Ipomoea pescaprae

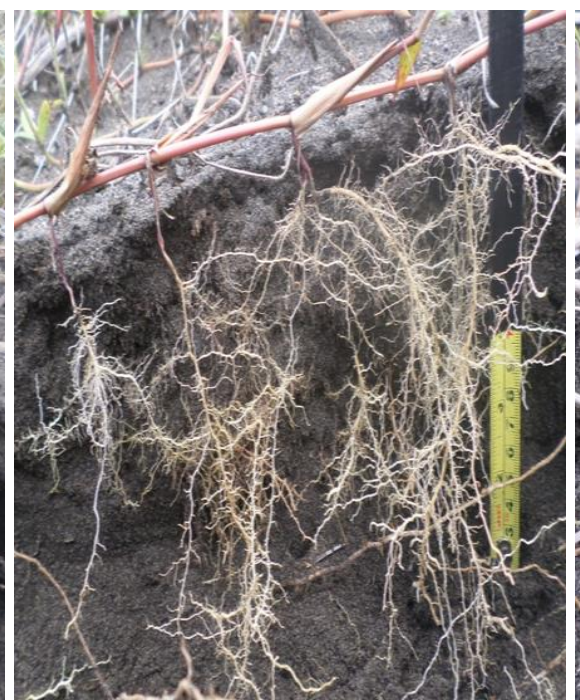

E. Cynodon dactylon

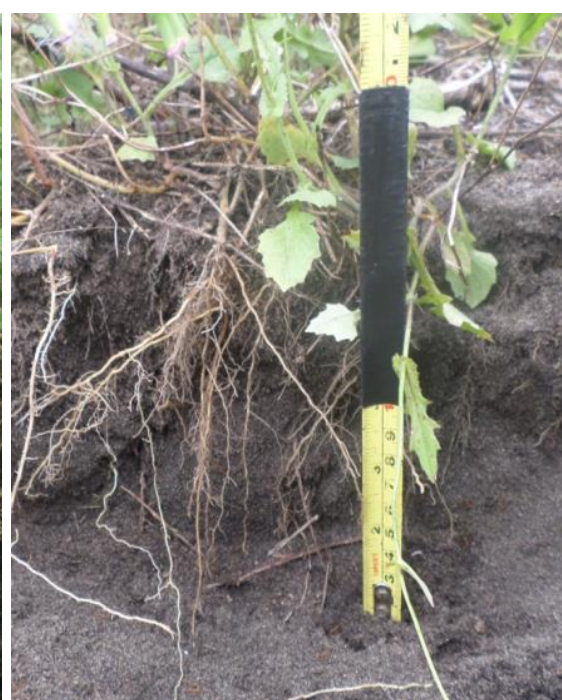

H. Emilia sonchifolia

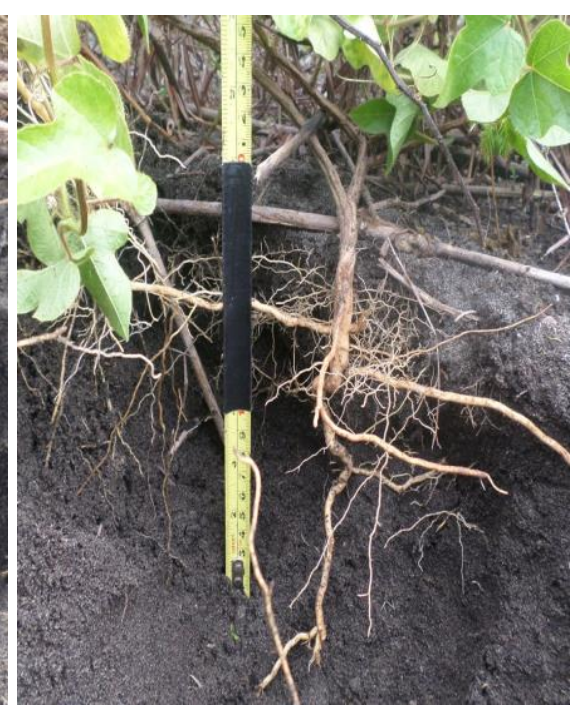

C. Passiflora foetida

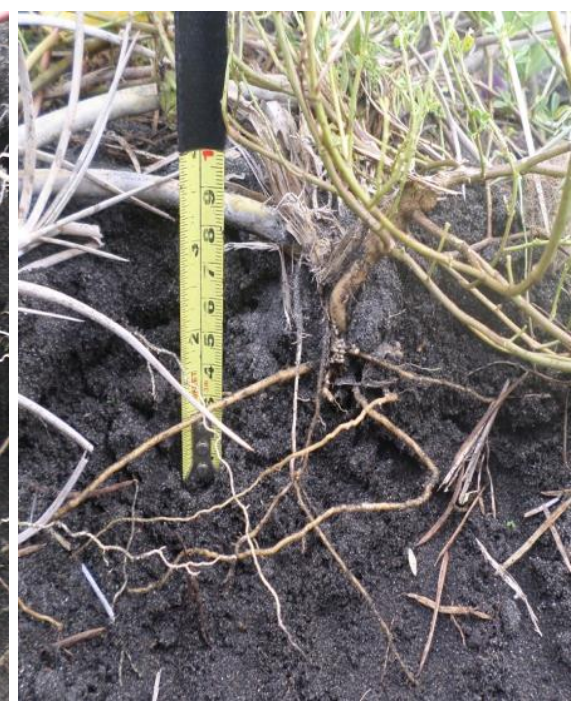

F. Borreria sp.

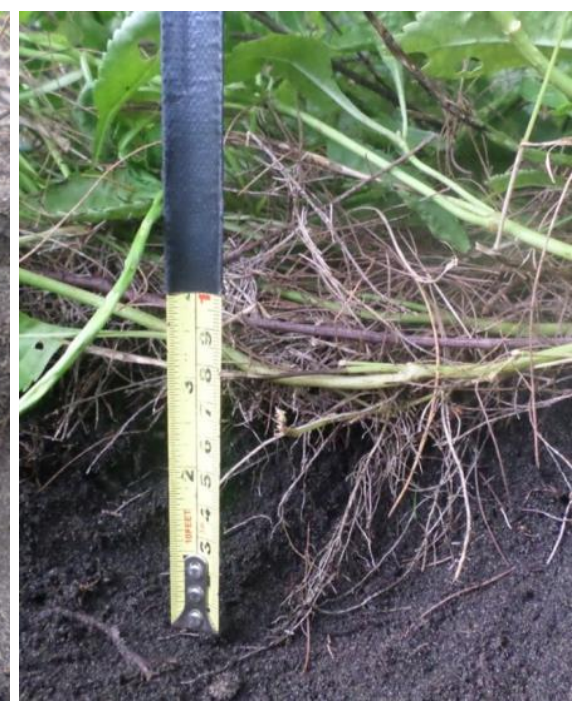

I. Stachytarpheta indica

Gambar 3. Perakaran tumbuhan bawah di pesisir Lembupurwo.

A. Bulbustylis barbata, B. Ipomoea pescaprae, C. Passiflora foetida, D. Spinifex littoralis, E. Cynodon dactylon, F. Borreria sp., G. Porophyllum ruderale, H. Emilia sonchifolia, I. Stachytarpheta indica 


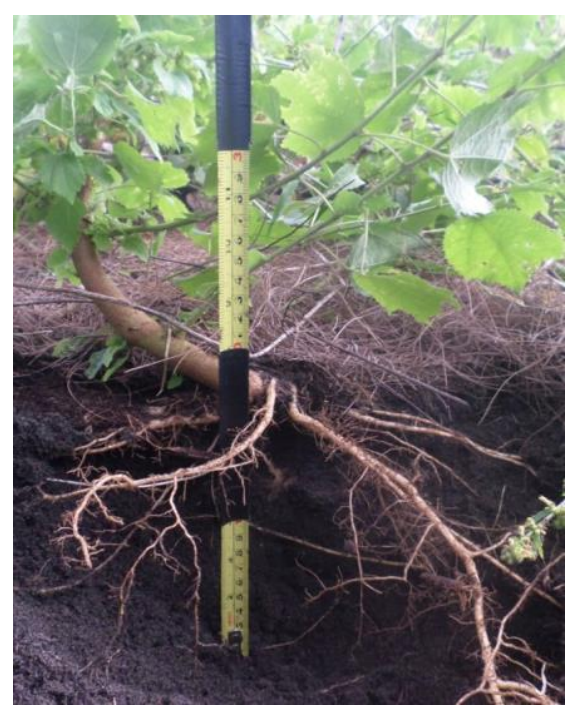

A. Abutilon pictum

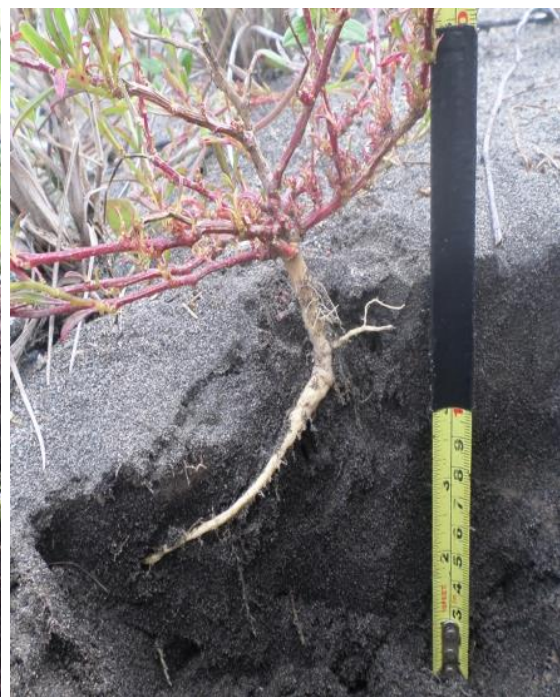

B. Portulaca oleracea

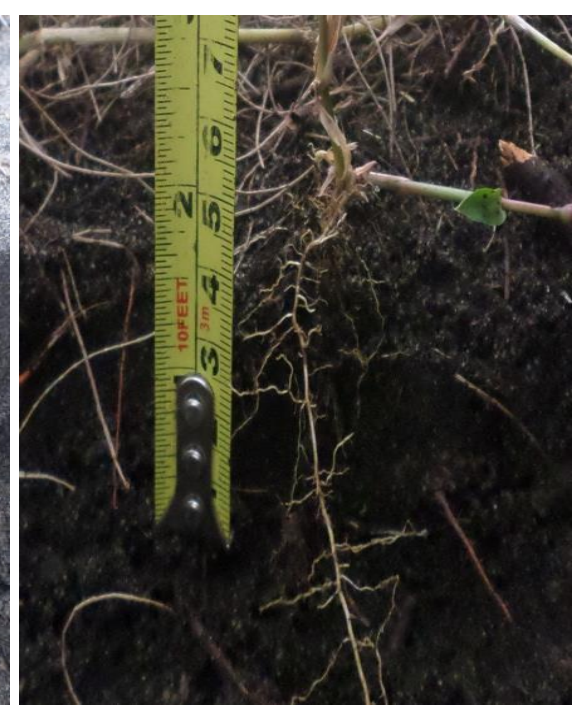

C. Panicum repens

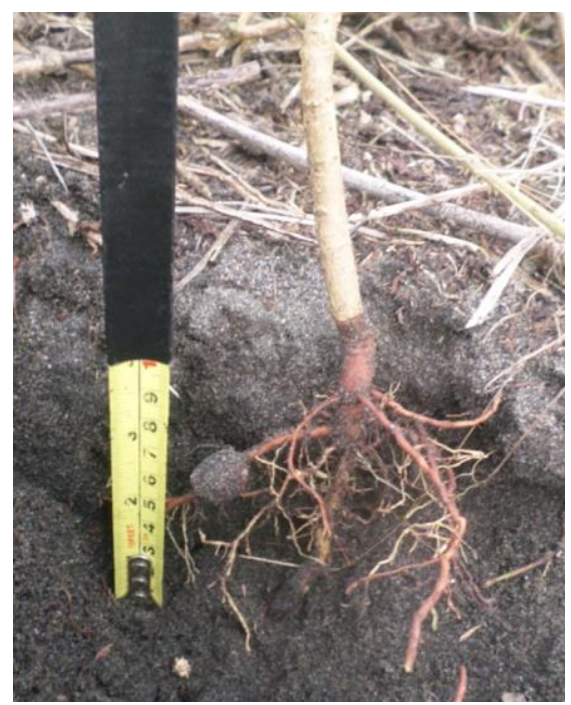

D. Borreria leavis

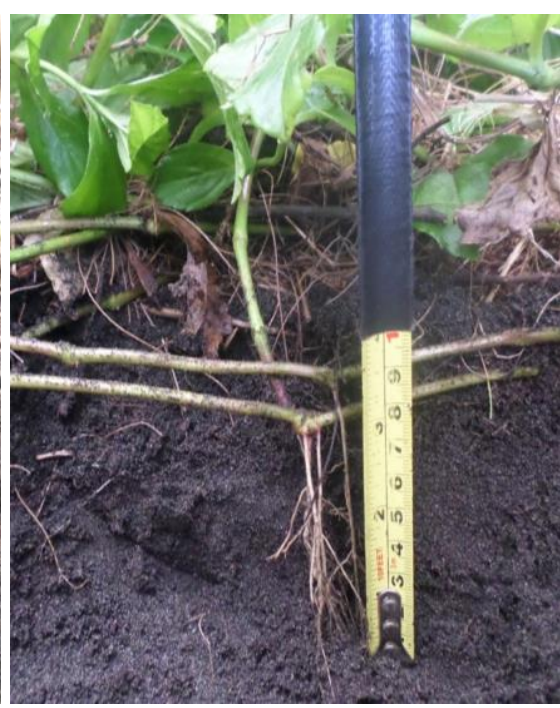

E. Wedelia biflora

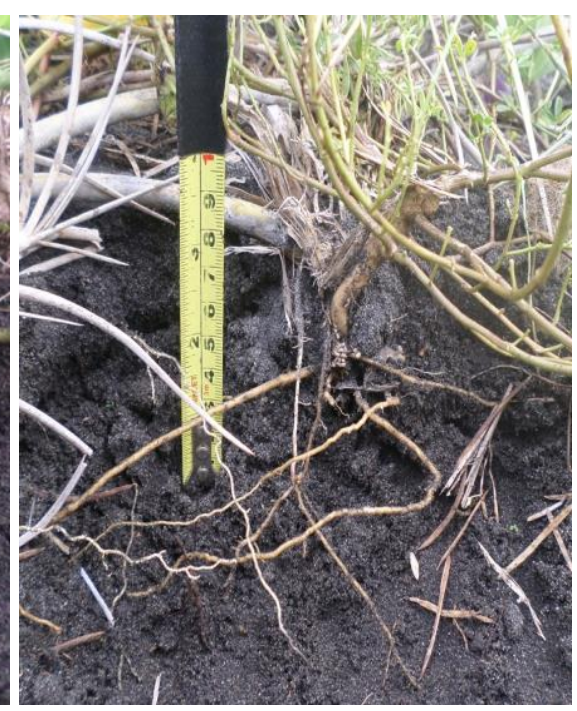

F. Salvia divinorum

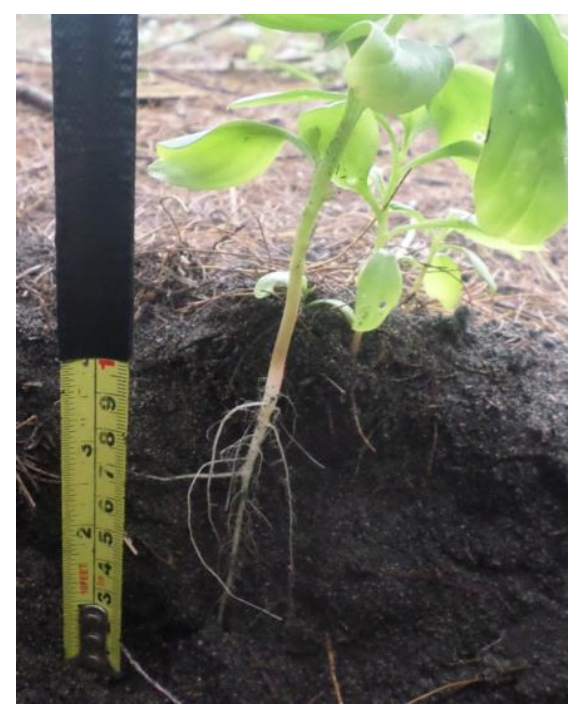

G. Elephantopus spicatus

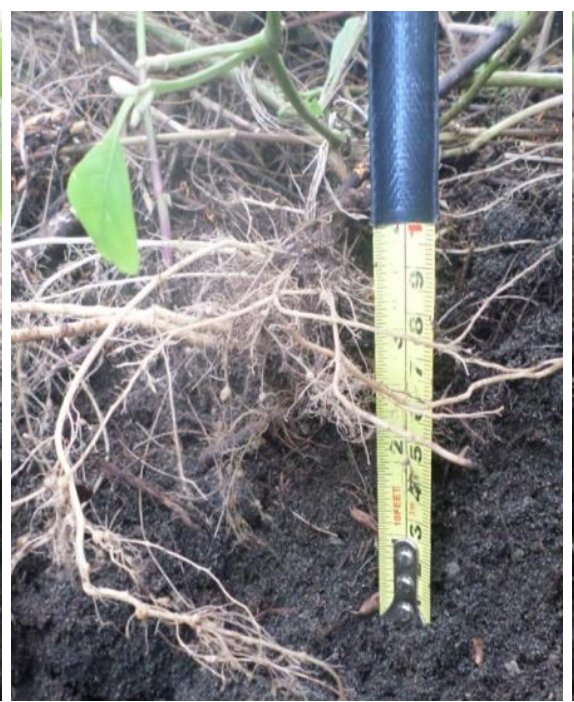

H. Coleus parfiflorus

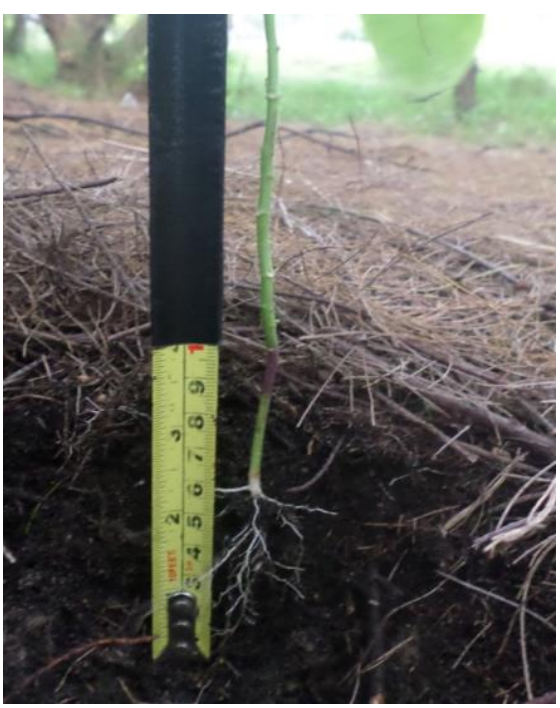

I. Solanum sp.

Gambar 4. Perakaran tumbuhan bawah di pesisir Lembupurwo.

A. Abutilon pictum, B. Portulaca oleracea, C. Panicum repens, D. Borreria leavis, E. Wedelia biflora, F. Salvia divinorum,

G. Elephantopus spicatus, H. Coleus parfiflorus, I. Solanum sp. 
Jenis perakaran tumbuhan bawah di kawasan pesisir Lembupurwo terdiri dari akar tunggang dan akar serabut. Spinifex littoralis tercatat memiliki akar yang relatif lebih panjang dibandingkan dengan tumbuhan bawah lainnya. Spinifex littoralis merupakan jenis herba yang adaptif terhadap kondisi pesisir yang cukup ekstrim, dan memiliki batang yang dapat tumbuh menjalar di atas permukaan tanah, sehingga jenis ini juga ditemukan dengan tutupan (coverage) paling luas (Steenis, 1947).

Tumbuhan bawah dengan rerata akar terpanjang ditemukan pada daerah di belakang tegakan Cemara Udang, sedangkan yang terpendek ditemukan pada daerah di bawah tegakan Cemara Udang (Gambar 2). Hal ini dikarenakan pada daerah tersebut memiliki intensitas cahaya dan suhu paling tinggi yang membatasi pertumbuhan perakaran jenis tumbuhan bawah. Hal tersebut juga disebabkan karena tidak adanya pohon yang dapat membantu meningkatkan kandungan bahan organik di dalam tanah melalui proses dekomposisi seresah, sehingga akar tumbuhan akan mencari unsur hara dengan jangkauan yang lebih luas. Menurut Islami \& Utomo (1995), untuk mendapatkan pertumbuhan yang baik, tanaman harus mempunyai akar dan sistem perakaran yang cukup luas sehingga dapat memperoleh hara dan air sesuai dengan kebutuhan tanaman. Umumnya kondisi pertumbuhan tanaman di lapangan tidak berada pada keadaan optimum, maka adanya sistem perakaran yang dalam dan luas sangat diperlukan oleh tanaman agar dapat tumbuh dengan baik.

Pertumbuhan akar sangat dipengaruhi oleh keadaan fisik tanahnya. Tanah merupakan tempat berkembangnya akar pohon serta interaksi hara dengan pohon, maka pemadatan tanah dan kandungan air tanah akan mempengaruhi kualitas pertumbuhan akar pohon (Rusdiana, et al., 2000). Berdasarkan hasil analisis, dapat diketahui bahwa pertumbuhan akar vertikal dan horizontal dipengaruhi oleh intensitas cahaya, kandungan Ktersedia, dan suhu tanah. Menurut Soerianegara dan Indrawan (2005), cahaya merupakan faktor yang sangat penting dalam pertumbuhan, yaitu sebagai sumber energi dan menjadi energi dasar untuk meningkatkan berbagai proses enzim yang terlibat dalam rangkaian proses metabolisme dan fotosintesis.

Hubungan positif yang sangat kuat antara Ktersedia dengan kemerataan jenis tumbuhan bawah pada lokasi penelitian dibuktikan dengan nilai koefisien korelasi ( $\mathrm{r}$ ) yang mencapai 1 dan nilai signifikasi sebesar 0,008. Dapat disimpulkan bahwa unsur K-tersedia memberikan pengaruh terhadap kemerataan jenis tumbuhan bawah yang tersebar di lokasi penelitian. Menurut Indranada (1986), Kalium sangat mudah diserap oleh tanaman dan akan bergerak dari jaringan-jaringan tua ke titik-titik pertumbuhan akar dan tajuk. Mas'ud (1993) menjelaskan bahwa kebutuhan $\mathrm{K}$ dan pola pengambilan $\mathrm{K}$ tergantung pada jenis tanaman dan tingkat pertumbuhan tanaman.

Struktur tegakan merupakan gambaran variasi kondisi tegakan yang terbentuk sebagai hasil interaksi antara kondisi biofisik dengan kondisi vegetasi yang terdapat di dalam ekosistem hutan. Selain berfungsi untuk menggambarkan dinamika hutan, struktur tegakan juga menjadi indikator untuk menilai proses regenerasi vegetasi pada suatu ekosistem (Clutter et al., 1983).

Tabel 6. Hasil analisis korelasi antara faktor lingkungan terhadap struktur dan komposisi jenis tumbuhan bawah di pesisir Lembupurwo

\begin{tabular}{|c|c|c|c|c|c|c|c|c|c|c|c|c|c|c|}
\hline \multirow{2}{*}{$\begin{array}{l}\text { Faktor } \\
\text { Lingkungan }\end{array}$} & \multicolumn{2}{|c|}{ Jumlah Individu } & \multicolumn{2}{|c|}{ Komposisi } & \multicolumn{2}{|c|}{ Keanekaragaman } & \multicolumn{2}{|c|}{ Kekayaan } & \multicolumn{2}{|c|}{ Kemerataan } & \multicolumn{2}{|c|}{ Akar Vertikal } & \multicolumn{2}{|c|}{ Akar Horisontal } \\
\hline & $\mathbf{r}$ & Sig & $\mathbf{r}$ & Sig & $\mathbf{r}$ & Sig & $\mathbf{r}$ & Sig & $\mathbf{r}$ & Sig & $\mathbf{r}$ & Sig & $\mathbf{r}$ & Sig \\
\hline pH tanah & $-0,701$ & 0,505 & $-0,767$ & 0,444 & $-0,522$ & 0,650 & $-0,783$ & 0,427 & $-0,122$ & 0,922 & $-0,118$ & 0,925 & $-0,232$ & 0,851 \\
\hline $\mathrm{N}$ total & 0,380 & 0,752 & 0,468 & 0,690 & 0,162 & 0,896 & 0,491 & 0,674 & $-0,262$ & 0,831 & $-0,484$ & 0,678 & 0,582 & 0,604 \\
\hline P tersedia & 0,592 & 0,597 & 0,667 & 0,535 & 0,395 & 0,742 & 0,686 & 0,519 & $-0,022$ & 0,986 & 0,259 & 0,833 & 0,370 & 0,759 \\
\hline $\mathrm{K}$ tersedia & $-0,786$ & 0,425 & $-0,722$ & 0,486 & $-0,905$ & 0,280 & $-0,704$ & 0,503 & 1,000 & 0,008 & 0,974 & 0,145 & 0,941 & 0,219 \\
\hline Suhu Tanah & $-0,290$ & 0,813 & $-0,381$ & 0,751 & $-0,067$ & 0,957 & $-0,405$ & 0,735 & 0,353 & 0,770 & $-0,566$ & 0,617 & $-0,657$ & 0,543 \\
\hline DHL & 0,349 & 0,773 & 0,438 & 0,712 & 0,129 & 0,918 & 0,461 & 0,695 & $-0,294$ & 0,810 & 0,513 & 0,657 & 0,609 & 0,583 \\
\hline
\end{tabular}

Tabel 7. Hasil analisis korelasi antara faktor lingkungan dan tanah terhadap perakaran tumbuhan bawah di pesisir Lembupurwo

\begin{tabular}{|c|c|c|c|c|}
\hline \multirow{2}{*}{ Parameter } & \multicolumn{2}{|c|}{ Akar Vertikal } & \multicolumn{2}{|c|}{ Akar Horisontal } \\
\hline & Koef. Korelasi & Signifikasi & Koefisien Korelasi & Signifikasi \\
\hline Lux Awal & 0,673 & 0,047 & 0,434 & 0,243 \\
\hline Lux Akhir & $-0,060$ & 0,878 & 0,036 & 0,926 \\
\hline Suhu Awal & $-0,407$ & 0,277 & $-0,584$ & 0,099 \\
\hline Suhu Akhir & $-0,353$ & 0,352 & $-0,319$ & 0,402 \\
\hline Kelembaban Awal (\%) & $-0,479$ & 0,192 & $-0,220$ & 0,570 \\
\hline Kelembaban Akhir (\%) & 0,174 & 0,654 & 0,432 & 0,246 \\
\hline Kec. Angin Awal (km/s) & $-0,567$ & 0,111 & $-0,500$ & 0,171 \\
\hline Kec. Angin Akhir (km/s) & $-0,099$ & 0,799 & $-0,121$ & 0,757 \\
\hline $\mathrm{pH}$ & $-0,417$ & 0,264 & $-0,194$ & 0,618 \\
\hline DHL $(\mu \mathrm{s} / \mathrm{cm})$ & 0,442 & 0,233 & 0,304 & 0,426 \\
\hline $\mathrm{N}$ total $(\%)$ & 0,125 & 0,749 & 0,102 & 0,795 \\
\hline P tersedia (ppm) & $-0,274$ & 0,475 & $-0,106$ & 0,786 \\
\hline $\mathrm{K}$ tersedia (me/100g) & 0,913 & 0,001 & 0,649 & 0,059 \\
\hline Akar Vertikal & & & 0,822 & 0,007 \\
\hline Suhu Tanah & $-0,718$ & 0,029 & $-0,779$ & 0,103 \\
\hline
\end{tabular}




\section{K E S I M P U L A N}

Tegakan Cemara Udang berpengaruh terhadap komposisi dan struktur vegetasi tumbuhan bawah serta beberapa faktor lingkungan wilayah pantai. Komposisi tumbuhan bawah di bawah tegakan Cemara Udang lebih tinggi dibanding di luar tegakan Cemara Udang. Perakaran jenis tumbuhan bawah yang tumbuh di bawah tegakan Cemara Udang lebih pendek dibanding perakaran jenis tumbuhan bawah yang tumbuh di luar tegakan Cemara Udang.

\section{DAFTAR REFERENSI}

Alik TSD, Umar MR, Priasambodo D. 2012. Analisis vegetasi mangrove di pesisir pantai Mara' Bombang - Kabupaten Pinrang. Jurnal Ilmiah. Makassar: Jurusan Biologi Fakultas Matematika dan Ilmu Pengetahuan Alam Universitas Hasanuddin.

Atmanto WD. 2013. potensi simbiosis Casuarina-Frankia dalam meningkatkan kualitas tanah di lahan pasir pantai [disertasi] Ilmu Kehutanan. Universitas Gadjah Mada. Yogyakarta.

Barbour GM, Burk HJ, Pitt WD. 1980. Terrestial plant ecology. London: The Benjamin Publishing Company.

Clutter JL, Fortson JC, Pienaar LV, Brister GH, Bailey RL. 1983. Quantitative timber management. New York: John Wiley \& Sons, Inc.

Dombois DM, Ellenberg H. 1974. Aims and methods of vegetation Ecology. New York: John Willey and Sons.

Dommergues Y. 1990. Casuarina equisetifolia: An older time with a new future, NFT Highlight. Waimanalo USA: Publication of the Nitrogen Fixing Tree Association, PO Box 680.
Hardjowigeno S. 1987. Ilmu tanah. Jakarta: PT. Medyatama Sarana Perkasa.

Indranada HK. 1986. Pengelolaan kesuburan tanah. Bandung: Bina Aksara.

Islami T, Utomo WH. 1995. Hubungan tanah, air dan tanaman. Semarang: IKIP Semarang Press.

Ludwig JA, Reynolds JF. 1988. Statistical ecology, a primer on methods and computing. New York: John Willey and Sons.

Mas'ud P. 1993. Telaah kesuburan tanah. Bandung: Angkasa.

Rao NSS, Dommergues YS. 1998. Microbial interaction in agriculture and forestry. USA: Science Publishers, Inc.

Raymond G. 2010. Pengelolaan hutan mangrove berbasis masyarakat di Kecamatan Gending, Probolinggo. Agritek. Vol.18 No.2 April 2010.

Rusdiana O, Yahya F, Kusmana C, Hidayat Y. 2000. Respon pertumbuhan akar tanaman sengon (Paraserianthes falcataria) terhadap kepadatan dan kandungan air tanah podsolik merah kuning. Jurnal Managemen Hutan Tropika. 6 (2) : 43-53.

Soegianto. 1983. Kenalilah flora pantai kita. Jakarta: Widjaya.

Soerianegara I, Indrawan A. 2005. Ekologi hutan Indonesia. Departemen Manajemen Hutan. Fakultas Kehutanan IPB. Bogor.

Steenis CGGJV. 1947. Flora untuk sekolah di Indonesia. Jakarta Pusat: PT. Pradnya Paramita..

Whistler WA, Craig R, Elevitch. 2006. Species profiles for Pacific Island Agroforestry. Hawai: Permanent Agricultural Resources (PAR), Holualoa.

Whittaker RH. 1975. Tropical rain forest of The Far East. London: Oxford University Press.

Winarni WW. 2002. kesesuaian jenis untuk rehabilitasi kawasan pantai Daerah Istimewa Yogyakarta. Laporan Penelitian DPP. Yogyakarta: Fakultas Kehutanan UGM. 